OPEN ACCESS

Vol. 7, No. 1, April, 2019

Page. $1-43$

DOI: https://doi.org/10.21107/jaffa.v7i1.6183
JOURNAL OF AUDITING, FINANCE, AND FORENSIC ACCOUNTING (JAFFA)

E-ISSN: 2461-0607 ISSN: 2339-2886

https://journal.trunojoyo.ac.id/jaffa/index

\title{
EFFECTS OF GOVERNANCE MEDIATION ON THE RELATIONSHIP BETWEEN ENTERPRISE RISK MANAGEMENT AND FINANCIAL PERFORMANCE
}

\section{Nurhayati}

Accounting Departement, Faculty of Economics and Business, University of Trunojoyo Madura

\section{Article Info:}

Received: 5 Juli 2019

in revised form: 19 Juli 2019

Accepted: 21 November 2019

Available Online: 19 December 2019

\section{Keywords:}

ERM Framework, Performance, Higher Education Governance

Corresponding Author:

Email: yatikmei77@gmail.com

\begin{abstract}
This study explains the effects of mediating the role of university governance elements on the relationship between implementation of ERM and financial performance. The background of this research is inconsistency in prior studies and the phenomenon of low accountability at universities and the existence of low internal control function. Based on the final report of Supervision, Control and Development (WASDALBIN) for the period of 2016 indicates that private universities not accredited yet are 52\%. The data collection techniques applied survey methods and the data analysis techniques used Structural Equation Modeling (SEM) PLS. The results show that ERM significantly affect financial performance through the role of university governance elements.
\end{abstract}

Abstrak; Studi ini menjelaskan efek mediasi peran elemen tata kelola universitas pada hubungan antara implementasi ERM dan kinerja keuangan. Latar belakang penelitian ini adalah inkonsistensi dalam studi sebelumnya dan fenomena akuntabilitas yang rendah di universitas dan adanya fungsi kontrol internal yang rendah. Berdasarkan laporan akhir Pengawasan, Pengendalian dan Pengembangan (WASDALBIN) untuk periode 2016 menunjukkan bahwa universitas swasta yang belum terakreditasi adalah 52\%. Teknik pengumpulan data menggunakan metode survei dan teknik analisis data menggunakan Structural Equation Modeling (SEM) PLS. Hasil penelitian menunjukkan bahwa ERM secara signifikan mempengaruhi kinerja keuangan melalui peran elemen tata kelola universitas. 


\section{INTRODUCTION}

This research empirically explores effects of implementation of the Enterprise Risk Management (ERM)-based COSO Framework 2004 that is mediated by role of governance element on college performance. This study is motivated by several reasons; the first is inconsistency of findings in previous studies related to the 1992 COSO framework compared to the 2004 COSO framework. Second, there is few researches exploring the effect of the COSO framework on performance with inconsistent findings. One of the missions of COSO adopted by one of the board members in 2008 is to improve the performance of the organization and government (Landsittel dan Rittenberg, 2010). Ballantyne (2013) stated that adoption of ERM was not only related to financial performance and the adoption of ERM was not enough to improve the company's financial performance. Other research findings also provided little evidence that ERM associated with capital efficiency, profitability, number of shareholders, or firm value. The results did not provide evidence of an inverse correlation between ERM maturity and volatility, which indicates that the ERM can effectively reduce an enterprise's risk to invest in the resources needed in the ERM process. Third, over a very long period from 1985 to the 2000s, the growing empirical research was only directed to private sector organizations focusing on minimizing financial statement fraud. In fact, the mission and purpose of establishing COSO is not only for private sector organizations but also educational institutions.

The phenomenon was found in the 2016 accreditation report was that there were still many universities that had not been accredited. As evidenced, it was only $59 \%$ or 190 private universities in East Java that had been accredited from a total of 322 private universities. The final report on Supervision, Control, and Coaching (WASDALBIN) in 2016 showed that private universities whose institutions had not been accredited remained 52\%. This shows the low level of accountability in tertiary institutions, both financial and non-financial, and the poor internal control function (Nurhayati, 2016). The findings on private universities Supervision, Control, and Coaching of Private University Coordinator Region VII in 2016 also concluded that 289 private universities had formed the Internal Quality Assurance System Team (91\%), but the team did not meet an overall higher education quality assurance cycle. This was proven, as many as 161 private universities (50.15\%) of the formation of the Internal Quality Assurance System Team were only formed as a formality, in the sense of not having performed a cycle of setting, implementing, evaluating, controlling, and continuously improving standards. The Internal Quality Assurance System is a crucial element that can guarantee the quality of an institution and should be balanced with an overall higher education quality assurance cycle.

The research of Popescu and Dascalu (2012) stated that the COSO framework was used in improving internal control systems in Romanian universities, which was supported by Christopher and Sarens (2015) stating the application of risk management by several state universities in Australia had different implications. As it was affected by NPM that was not congruent with organizational culture, in which it was operational. Several research using risk assessment approach in internal audit by referring to the 1992 COSO framework such as Ramamoorti et al. (1999) stated that the COSO framework could help the Internal Auditor assess risk in several aspects including finance, operations, and compliance based on the Neural Network approach. Furthermore, Chen et al. (2007) stated that by using the logistic regression approach in reconstructing risk-based internal control, an accuracy of $75 \%$ was obtained that the phenomenon of Enron's financial scandal is caused by poor internal control.

Research gaps and phenomena in Supervision, Control, and Guidance motivate researchers to conduct research related to the effects of implementing the COSO-ERM framework and the role of governance elements in higher education to improve performance of higher education in East Java. This research identifies several important research problems to be analyzed, supported by phenomena in the education field that indicate poor internal control functions and declining performance at higher education. Internal control does not only include the Internal Audit Unit (SPI) in university but also the entire control environment in the university which plays an important role in improving performance of university, both financially and non-financially, along with competency and morality. The COSO Framework is an internal control spirit that is 
feasible to be implemented in various organizations. Internal control is not only supported by a good control system but requires the presence and role of all elements of higher education governance such as the top Manager (management). This research examines the models of various research related to the effect of COSO ERM framework that is mediated by the role of Higher Education Governance elements on financial performance in Higher Education in East Java.

\section{LITERATURE REVIEW AND HYPOTHESES DEVELOPMENT}

Based on the stewardship theory, maximizing utility of a group will ultimately maximize interests of individuals in the group organization. Steward (management) protects and maximizes shareholders (Government) through university performance. Steward who can successfully improve university performance will be able to satisfy most other organizations stakeholders. Therefore, stewards who are pro-organization (university) are motivated to maximize the performance of university and meet interests of shareholders. Madison (2014) in his dissertation stated that the integration of agency theory and the stewardship theory were empirically proved to affect organizational behavior and performance. Stewardship theory describes the situation of leaders who are not motivated by individual goals, but rather aimed at the main target for benefit of the organization. Hence, the steward (management) acts according to the ecpectation of the principal. The context of this research is the quality of university performance, the presence of management and internal auditors who tend to behave in accordance with the perspective of management theory (stewardship theory). A rational actor who is not motivated by his individual desires, but rather as a recipient of the mandate (stewardship) who has motives that are in line with the principal's goals.

\section{Hypothesis Development}

Previous research indicated that the COSO-ERM framework affects performance (Gordon et al. (2009); Christ et al. (2012); Salehi et al. (2013); Ballantyne (2013); Brown et al. (2014); Fan (2014); Ahmed dan Manab (2016). However, there are some researchers stating that the implementation of COSO ERM does not directly mention the effect on performance but it affects the quality of earnings according to Brown et al. (2014); affects the company's operations according to Mei F. Chanli dan Sarah E. Mcvay (2015); and is also an internal control instrument as a preventive and detective of financial statements or fraud (Chen, Shaio Yan et. al. (2007); Altamuro (2010); Baxter (2013); Abiola dan Oyewole (2013); Kulikova dan Satdarova (2016); Dut (2016)). This shows that COSO ERM has been empirically stated to have an effect on organizational performance from a different perspective. However, according to Christopher and Sharen (2015), ERM is not congruent with culture in Australia so that it has a different impact on the outcome. This research leads to a managerial approach producing quality performance considering sociological and psychological factors based on the stewardship theory and Islamic leadership theory. The implication of Stewardship theory for this study explains the existence of Higher Education as an institution that can be trusted to act in accordance with the public interest by performing its functions and duties appropriately, making financial responsibilities mandated to. So, the steward (Higher Education management) leads the ability and expertise in streamlining internal control to produce quality financial and non-financial information statements. Madison (2014) stated that stewardship theory was empirically proved to affect organizational behavior and performance. Based on this description, the research hypothesis is: H1: Enterprise Risk Management affects the Performance of Higher Education.

Empirical researches states that roles, abilities, and structure of an Audit Committee affects performance of organizations and companies (Loana and Mariana (2004); Drymiotes (2008); Alabede and Tony (2015); Mensah (2015)) and BOD (Board of Directors) diversity is positively correlated to companies' performance (Farag and Mallin, 2016). However, Collum (2014) stated that in the United States Medical Cost Reports Hospital, structure of the BOD would affect performance if there is compensation for the BOD. In other words, some payment or compensation given to the BOD significantly 
mediates the relationship between the BOD structure and financial performance of the Hospital. BOD in the higher education is referred to the Policy Formulation Element, for a legal entity State University is a board of trustees and for State University and Private University is the Senate responsible to the minister and Private University is responsible to the Organizer.

Beasley et al. (2005) stated that factors associated with ERM were presence or role of the BOD. So that the BOD communication process and the internal Auditor will affect the quality of the Financial Statements Cohen et al. (2007). Nevertheless, Yatim (2009) stated that in addition to a strong BOD structure; company size, complexity of company operations, and use of the Big Four Public Accountant Firms affect the relationship between risk management and the BOD structure of companies registered in Malaysia. Based on the description, the research hypothesis is: H2: Higher Education Governance mediates the relationship between Enterprise Risk Management and Higher Education performance.

\section{RESEARCH METHODOLOGY}

This research is explanatory study, in which there is three types of variables. The independent variable is the Enterprise Risk Management, an integrated risk-based internal control framework affected by board of directors of an entity, management, and other personnel in the entity (Rittenberg, 2013). The dependent variable is performance. Intervening variable is the Role of Higher Education Governance Elements. The measurement scale of the UTKPT (Elements of Higher Education Governance) role variable uses Likert scale to capture the attitudes and perceptions of respondents towards the role of the UTKPT involvement based on their duties and functions. The population in this research is state and private university in the East Java with a minimum accreditation of $\mathrm{C}$. The sample in this research are all members of the population who are sampled (saturated sample). Data collection techniques used in this research are secondary data documentation techniques and survey methods using a questionnaire. Secondary data sources include data on institutional accreditation forms and financial statements of institutions. The target respondents are the Management / Chairman or Vice Chairman of the Internal Supervisory Unit and / or the Management / Chairman or Vice Chairman of the Quality Assurance Agency of Higher Education.

\section{FINDINGS AND DISCUSSION}

Initially, 40 copies of questionnaire were distributed with target respondent was the control environment including the function of senate, academic implementers, supervisors and/or quality assurance and lecturers (teaching staff) also doubling as vice deans at various state and private universities. Selection of target respondents was to measure attitudes or perceptions of ERM implementation, the role of higher education governance elements and assessment of leaders in leading and managing higher education. The validity and reliability test of the research instrument were performed as a condition to assess the outer model (measurement model) in evaluating the correlation between indicators and constructs before assessing and estimating the inner model (structural model). The test results show the loading factor of convergent validity above 0.70 and significant ( $p$ values $<0.05$ ). Discriminant validity has also been fulfilled, that is, the AVE roots in diagonal column are higher than correlations between constructs in the same column. Whereas, construct reliability shows composite reliability and Cronbach alpha above 0.70. Overall results of the measurement model (outer model) of reflective construct have met requirements so that they can proceed to structural model (inner model) for testing the model.

Statistical test instrument used was Smart-PLS through measurement models and structural models. Based on statistical analysis, it is shown a summary of the results of the research hypothesis testing, as follows: 
Table 4. 1. Hypothesis Testing

\begin{tabular}{|l|l|}
\hline & \multicolumn{1}{|c|}{ Conclusion } \\
\hline Hypothesis 1 & Supported \\
\hline Hypothesis 2 & Supported \\
\hline
\end{tabular}

This research concludes that the implementation of Enterprise Risk Management can affect financial performance. Enterprise Risk Management is an integrated riskbased internal control framework that can have a positive impact on performance of university. The findings of this research provide empirical evidence that the role of higher education governance elements provides evidence as a mediating variable of relationship between ERM and financial performance. The first hypothesis is tested, it is shown from the results of hypothesis testing that a high / strong ERM is able to improve financial performance as evidenced by magnitude of the parameter coefficient of 0.386 with a statistical value of 3.786 greater than the t table value of 1.96 and $p$ $<0.005$ which is 0.000 .

This research proves that the ERM framework is a risk-based internal control framework that is effective in improving financial performance. Likewise, the second hypothesis is also tested, shown from the results of testing the hypothesis that the role of the university governance element is able to act as a mediator of the relationship between ERM and financial performance, firstly, it can be seen that the ERM as a predictor variable had an effect on PUTKPT as a mediator variable as evidenced from magnitude of the parameter coefficient of 0.802 with a statistical value of 17.761 which was higher than the $t$ table value of 1.96 and $p<0.005$ which was equal to 0.000 (ERM against PUTKPT). Secondly, it is seen that PUTKPT as a mediator variable has an effect on KNRJ as a mediator variable. It is evidenced from magnitude of the parameter coefficient of 0.373 with a statistical value of 3.017 which is higher than the t table value of 1.96 and $\mathrm{p}<0.005$ which is equal to 0.003 (PUTKPT against KNRJ).

\section{Discussion}

The results show that a strong ERM can improve financial performance. It is consistent with COSO's mission through a comprehensive framework and guidelines for risk management, that internal control can prevent fraud and improve organizational performance as well as reduce the occurrence of fraud in the organization. The research results are in line with D'Aquila (2013) regarding the concept of integrated internal control framework by updating the original concept adapted to today's environment. The updating is based on current environmental needs, namely revising the original framework into three categories, namely board-based change approach; Changes in layout of the overall framework, related to improving organizational performance and reducing fraud. This is also in line with the research of Ahmed dan Manab (2016) stating that successful implementation of ERM affects company's performance both financially and non-financially.

The test results indicate that there is a role of higher education governance as a mediator in relationship between ERM and financial performance. It means that management / chairman of a quality control agency or an internal audit unit, which is an element of higher education governance, has responded positively to the ERM framework as a comprehensive internal control framework for risk management. The results of this research are in line with explanation concerning possible role of COSO ERM that can have an impact on performance both financially and non-financially (Ballantyne 2013; Fan 2014; Mei F. Chanli dan Sarah E. Mcvay 2015). Ahmed and Manab (2016) also explain the important role of BOD in assessment of internal control, which is an interfering effect (Morrill et al., 2012). This is confirmed by the research of Ping dan Muthuveloo (2015) that implementation of the ERM (Enterprise Risk Management) is found to have a significant effect on company's performance. In addition, monitoring by the BOD, company size, and company complexity is found to significantly affect the relationship between implementation of the ERM and company's performance. Moreover, important finding regarding mediating effect of the ERM in improving performance are also in line with studies of (Chen et al. 2007; Baxter et al. 
2013; Salifou 2015; Ahmed dan Manab 2016) describing that COSO-ERM can be used as a tool to reconstruct risk-based internal control, as an organizational strategy, and competitive advantage that affects the company's performance both financially and nonfinancially.

The involvement and role of higher education governance elements mediates the relationship of COSO-ERM with performance, it is in line with the statement of Ballantyne (2013) that adoption of the ERM will have implications to performance if there is involvement of executive leadership and integration of organizational culture. These results provide significant insights for organizations and leaders because they determine the most effective ways to manage risk in the future. Fan (2014) states that the effects of diversity or demographics of the board will be positively correlated with performance, especially directors who have financial expertise will moderate relationship between implementation of the ERM and company's value / performance. This is also supported by Mensah (2015) indicating relationship between ERM and performance will be positively correlated if there is a role and presence of CRO (Chief Risk Officer), AC (Audit Committee), and TM (Top Manager) in a company.

\section{CONCLUSIONS AND SUGGESTIONS}

Based on analysis of this research, it is found that role and involvement of higher education governance elements included; policy making elements, implementing elements, and supervision elements will improve performance of higher education. This research finds that Chairman of internal audit unit as well as Quality Assurance Agency as an element of university supervision responds positively to the importance of role and involvement of higher education governance elements to improve performance. The ERM internal control framework has a positive effect on performance. This research find that the ERM is a comprehensive framework for risk management that is well implemented in higher education. This research has several limitations, that is not all performance variable research instruments are performed by reading and matching accreditation forms data with respondents' answers. As not all universities attach secondary data (accreditation forms) needed. All research instrument data both predictor variables, mediator variables, and criterion variables are the result of respondents' interpretations / perceptions in answering the research questionnaire so that differences in interpretations with higher education governance elements may occur.

This research provides evidence that implementation of ERM has a positive effect on financial performance mediated by the role and involvement of UTKPT. This research provides insight into accountants (internal auditors) about understanding guidelines or control frameworks that can improve organizational performance (Higher Education) by considering the role and involvement of all elements of governance in Higher Education. This research is expected to be one of references regarding concept of internal control based on the 2004 COSO-ERM framework using the COSO 2013 instrument in Higher Education. This research also provides a new research instrument that can be used by higher education based on role and involvement of the UTKPT in fostering and supervising higher education public accountability in accordance with Government Regulation No. 4 of 2014 on the implementation of higher education and higher education governance and Minister of Education and Culture Regulation No. 139 of 2014 concerning statute guidelines and university organizations. 


\section{REFERENCES}

Ahmed, I. dan Manab, N. A. (2016). Influence of Enterprise Risk Management Success Factors on Firm Financial and Non-financial Performance: A Proposed Model. International Journal of Economics and Financial Issues, 6(3), 830-836.

Alabede, J. O. dan Tony, M. (2015). Board Structures and Financial Performance of UK Top Firms: An Investigation of the Moderating Role of the Directors'Compensation. Issues in Social and Environmental Accounting, 9(3), 219-234.

Ballantyne, R. (2013). An Empirical Investigation Into The Association between Enterprise Risk Management and Firm Financial Performance. Lawrence Technological University, Dissertation Publishing Proquest, 3557261.

Baxter, R., Bedard, J. C., Hoitash, R. dkk. (2013). Enterprise risk management program quality: Determinants, Value Relevance, and the Financial Crisis. Contemporary Accounting Research, 30(4), 1264-1295.

Beasley, M. S., Clune, R., dan Hermanson, D. R. (2005). Enterprise risk management: An empirical analysis of factors associated with the extent of implementation. Journal Of Accounting and Public Policy 24, 521-531.

Brown, N. C., Pott, C., dan Wompener, A. (2014). The effect of internal control and risk management regulation on earnings quality: Evidence from Germany. Journal Accounting Public Policy, 33, 1-31.

Chen, H. J., Shaio Yan, H., dan Lin, C.-S. (2007). An Internal Control Approach to the Construction of a Litigation Warning Model: An Application of Logistic Regression. International Journal of Management, 24(1), 164-173.

Christopher, J. dan Sarens, G. (2015). Risk management: Its adoption in australian public universities within an environment of change management - A Management Perspective. Australian Accounting Review, 25(1). doi: 10.1111

Cohen, J., Gaynor, L. M., Krishnamoorthy, G. dkk. (2007). Auditor Communications with the Audit Committe and the Board of Directors: Policy Recommendations and Opportunities for Future Research. Accounting Horizons, 21(2), 165-187.

Collum, T. (2014). Management Involvement on the Board of Directors and Hospital Financial Performance. Journal of Healthcare Management, 59:56.

D'Aquila, J. (2013). COSO's Internal Control Integrated Framework Updating the Original Concepts for Today's Environment. The CPA Journal, 83(10), 22-29.

Drymiotes, G. (2008). Managerial Influencing of Boards of Directors. Journal of Management Accounting Research, 20, 19-45.

Dut, M. A. (2016). The development of internal control to detect and prevent financial statement fraud. Northcentral University, ProQuest 10092275.

Fan, X. (2014). Enterprise Risk Management, Board Demographics, and Firm Performance. The University of Texas, ProQuest Dissertations Publishing 3639652.

Farag, H. dan Mallin, C. (2016). The Impact of Dual Board Structure and Board Diversity: Evidence from Chinese Initial Public Offerings (IPOs). Journal Business Ethics, 139, 333-349.

Gordon, L. A., Loeb, M. P., dan Tseng, C. Y. (2009). Enterprise risk management and firm performance: A Contingency Perspective Journal Accounting Public Policy, 28, 301-327. 
Hair, J. F., Hult, G. T. M., Ringle, C. M. dkk. (2014). A Primer On Partial Least Squares Struktural Equation Modeling (PLS-SEM). SAGE Publications: United States of America.

Landsittel, D. L. dan Rittenberg, L. E. (2010). COSO: Working with the Academic Community Accounting Horizons American Accounting Association, 24(3), 455469.

Madison, K. J. (2014). Agency Theory and Stewardship Theory Integrated, Expanded, and Bounded by Context: An Empirical Investigation of Structure, Behavior, and Performance within Family Firms. University of Tennessee, Knoxville, Dissertation Doctor of Philosophy.

Mensah, G. K. (2015). Enterprise Risk Management: Factors associated with effective Implementation. Capella University, ProQuest Dissertations Publishing 3745481.

Morrill, J. B., Morrill, C. K. J., dan Kopp, L. S. (2012). Internal Control Assessment and Interference Effects. Behavioral Research In Accounting, 24(1), 73-90. doi: 10.2308

Nurhayati. (2016). Revealing and Building the COSO Concept and Khalifatullah Fiil Ard Philosophy to Prevent and Detect the Occurence of Fraud Through Forensic Accounting. Procedia - Social and Behavioral Sciences, 219, 541-547.

Ping, T. A. dan Muthuveloo, R. (2015). The Impact of Enterprise Risk Management on Firm Performance: Evidence from Malaysia. Asian Social Science, 11(22).

Popescu, M. dan Dascalu, A. (2012). Improving The Internal Control System Within Universities. Bulletin of the Transilvania University of Brasov Economics Sciences, 5(1), 54.

Ramamoorti, S., Bailey, A. D., Jr., dan Traver, R. O. (1999). Risk assessment in internal auditing: a neural network approach. International Journal of Intelligent Systems in Accounting, Finance and Management, 8(3), 159.

Rittenberg, L. (2013). Updated COSO framework clarifies, broadens application: Larry Rittenberg, former COSO chair and author of a new book on the 2013 Internal Control-Integrated Framework, weighs in on the updates (Vol. 70, pp. 13): Institute of Internal Auditors, Inc.

Salehi, M., Arianpoor, A., dan Salehi, F. (2013). Investigating the Effect of Internal Audit on the Performance of Private Banks' System Journal of Accounting - Business dan Management, 20(1), 46-58.

Salifou, D. A. (2015). Analysis of the Effectiveness of COSO'S ERM Model on Organizations Strategy, Competitive Advantage, and Value: A Qualitative Study. Capella University. 